University of Nebraska - Lincoln

DigitalCommons@University of Nebraska - Lincoln

$10-1-2006$

\title{
Emended classification of xanthomonad pathogens on citrus
}

Norman W. Schaad

USDA-ARS

Elena Postnikova

USDA-ARS

George Lacy

Virginia Polytechnic Institute and State University, Blacksburg, VA

Aaron Sechler

USDA-ARS

Irina V. Agarkova

University of Nebraska-Lincoln, iagarkova2@unl.edu

See next page for additional authors

Follow this and additional works at: https://digitalcommons.unl.edu/plantpathpapers

Part of the Plant Pathology Commons

Schaad, Norman W.; Postnikova, Elena; Lacy, George; Sechler, Aaron; Agarkova, Irina V.; Stromberg, Paul E.; Stromberg, Verlyn K.; and Vidaver, Anne K., "Emended classification of xanthomonad pathogens on citrus" (2006). Papers in Plant Pathology. 96.

https://digitalcommons.unl.edu/plantpathpapers/96

This Article is brought to you for free and open access by the Plant Pathology Department at DigitalCommons@University of Nebraska - Lincoln. It has been accepted for inclusion in Papers in Plant Pathology by an authorized administrator of DigitalCommons@University of Nebraska - Lincoln. 
Authors

Norman W. Schaad, Elena Postnikova, George Lacy, Aaron Sechler, Irina V. Agarkova, Paul E. Stromberg, Verlyn K. Stromberg, and Anne K. Vidaver 


\title{
ERRATUM
}

\section{Emended classification of xanthomonad pathogens on citrus}

\author{
Norman W. Schaad ${ }^{\mathrm{a}, *}$, Elena Postnikova ${ }^{\mathrm{a}}$, George Lacy ${ }^{\mathrm{b}}$, Aaron Sechler ${ }^{\mathrm{a}}$, \\ Irina Agarkova ${ }^{\mathrm{c}}$, Paul E. Stromberg ${ }^{\mathrm{a}}$, Verlyn K. Stromberg ${ }^{\mathrm{b}}$, Anne K. Vidaver ${ }^{\mathrm{c}}$ \\ a ARS-USDA, Foreign Disease-Weed Science Research Unit, 1301 Ditto Avenue, Ft. Detrick, MD 21702, USA \\ ${ }^{\mathrm{b}}$ Department of Plant Pathology, Physiology, and Weed Science, Virginia Polytechnic Institute and State University, \\ Blacksburg, VA 24061, USA \\ ${ }^{\mathrm{c}}$ Department of Plant Pathology, University of Nebraska, Lincoln, NE 68588, USA
}

In the paper by Schaad et al. [24] on reclassification of several xanthomonads, nomenclatural errors were made. The name Xanthomonas smithii subsp. citri proposed for the former taxon $X$. campestris pv. citri ( $=X$. axonopodis pv. citri) is illegitimate. Following the reinstatement of $X$. citri (ex Hasse 1915) Gabriel et al. [9] as a validly published name, Young et al. [34] wrote that the reinstatement of this epithet was based on a description that was inadequate in terms of modern practice for the purpose of formal classification. This report was subsequently summarized by the International Committee on the Systematics of Bacteria (ICSB) Subcommittee on the Taxonomy of the Genus Pseudomonas and Related Organisms [32] as implying rejection of the epithet, which the Subcommittee itself appeared to endorse. As we now understand, in accord with the International Code of Nomenclature of Prokaryotes ('the Code' - hitherto the International Code of Nomenclature of Bacteria [14]) the Judicial Commission of the ICSP only may reject a name for precisely specified reasons (Rule 56a). We also misinterpreted the subsequent establishment of the pathovar "citri" within Xanthomonas axonopodis [29] as further evidence for rejection of reinstatement of $X$. citri [9]. Finally, believing that the epithet "citri" had been rejected, we followed rule 23a of the Code [14] and proposed an illegitimate specific epithet "smithii" (which also required establishing the subspecies epithet "smithii"

\footnotetext{
DOI of original article: 10.1016/j.syapm.2005.03.017

*Corresponding author.

E-mail address: norman.schaad@ars.usda.gov (N.W. Schaad).
}

replacing "malvacearum"; see rule 13a [14]). In fact, $X$. citri Gabriel et al. 1989 was a legitimate, validly published name that was allowed to fall into abeyance because of the inadequacies perceived in its description. Schaad et al. [24] indicated their support for the conclusions of Gabriel et al. [9] but included DNA-DNA reassociation data indicated as necessary by for modern classification [26,31]. One purpose of this note is to recognize by effective publication the species related to pathogenic xanthomonads of citrus. The second purpose is to avoid confusion in plant pathological literature by replacing the illegitimate subspecies name $X$. smithii subsp. "smithii" with $X$. citri subsp. "malvacearum". For that purpose, corrected protologues for those species and subspecies are reported here: $X$. citri subsp. citri and $X$. citri subsp. malvacearum; $X$. fuscans subsp. fuscans and $X$. fuscans subsp. aurantifolii; and $X$. alfalfae subsp. alfalfae and $X$. alfalfae subsp. citrumelonis.

We also present (Table 1) GenBank accession numbers for the intergeneric spacer (ITS) sequences for the type strains proposed in this note [24].

\section{Protologues}

Abbreviations for culture collections in which type strains are on deposit: ATCC $=$ American Type Culture Collection, Manassas, VA, USA; $\mathrm{CFBP}=$ Collection Francaise de Bacteries Phytopathogenes, Angers, France; ICMP = International Collection of Microorganisms from Plants, Auckland, New Zealand; $\mathrm{ICPB}=$ International Collection of Phytopathogenic 
Table 1. 16S-23S Ribosomal intergeneric spacer sequences for type strains [24]

\begin{tabular}{lll}
\hline Proposed name & Strain designation & GenBank accession \\
\hline Xanthomonas citri & & \\
$X$. citri subsp. citri & ATCC 49118 & DQ660898 \\
$X$. citri subsp. malvacearum & ATCC 9924 & DQ660901 \\
Xanthomonas fuscans & & \\
$X$. fuscans subsp. fuscans & ATCC 19315 & DQ660900 \\
$X$. fuscans subsp. aurantifolii & NCPPB 3236 & DQ660897 \\
Xanthomonas alfalfae & & DQ660896 \\
$X$. alfalfae subsp. alfalfae & ATCC 11765 & DQ660899 \\
$X$. alfalfae subsp. citrumelonis & ATCC 49120 & \\
\hline
\end{tabular}

Bacteria, USDA, Ft. Detrick, MD, USA; LMG = Laboratorium Microbiologie Gent, Gent, Belgium; $\mathrm{NCPPB}=$ National Collection of Plant Pathogenic Bacteria, York, England.

Xanthomonas citri (ex Hasse 1915) Gabriel et al. [9] emend.

Etymology: ci'tri. N.L. gen. n. citri of citrus.

Description: The description of the species $X$. citri is encompassed within the description of the genus Xanthomonas Dowson, 1939 [25] emend. Vauterin et al. [29] and within the description provided by Gabriel et al. [9]. X. citri subsp. citri causes bacterial canker on Citrus spp. and X. citri subsp. malvacearum causes angular leaf spot and black arm of cotton (Gossypium spp.) whereas $X$. campestris and $X$. axonopodis do not affect either host [24]. $X$. citri does not produce a brown water soluble pigment on common media as does $X$. fuscans and $X$. campestris pv. vignicola [24]. $X$. citri is differentiated from all other xanthomonads, except $X$. campestris pv. melonis and $X$. campestris pv. viticola, by fatty acid profiles [33]. Additionally, $X$. citri differs from $X$. campestris and most other pathovars, subspecies, and species of Xanthomonas by serology [1,28], SDS-PAGE analysis of membrane proteins [28,30], isozyme analysis [13], DNA-DNA reassociation assays [8,24,29], ITS sequencing [24], RFLP [9,15], and rep-PCR profiles [20].

Type strain: ICPB $10518=$ ATCC $49118=\mathrm{LMG}$ 9322.

Xanthomonas citri subsp. citri (ex Hasse 1915) Gabriel et al. 1989, subsp. nov.

Etymology: ci'tri. N.L. gen. n. citri of citrus.

Description: $X$. citri subsp. citri causes bacterial canker of citrus whereas $X$. citri subsp. malvacearum does not [24]. $X$. citri subsp. citri may be distinguished from $X$. campestris and most other Xanthomonas pathovars, subspecies, and species by DNA-DNA reassociation assays $[8,24,29]$, ITS sequencing [24], repPCR profiles [20], and phenotypic traits [24]. Strains of $X$. citri subsp. citri produce single colonies on YDC and FS agars [23] after 40-44 and 56-60 h, respectively at 28-30 ${ }^{\circ} \mathrm{C}$ [24]. In contrast, $X$. fuscans subsp. fuscans and
$X$. fuscans subsp. aurantifolii produce single colonies in 56-60 and 70-76h, respectively, and $X$. alfalfae subsp. alfalfae and $X$. alfalfae subsp. citrumelonis grow in 30-34 and 40-44h, respectively [24]. X. citri subsp. citri utilizes arabinose and lactose and hydrolyzes pectate whereas $X$. citri subsp. malvacearum does not [24]. $X$. citri subsp. citri reduces aspartic acid whereas $X$. campestris pv. campestris does not [24]. The latter utilizes raffinose and reduces saccharic acid whereas the former does not [24]. Both bacteria are differentiated by host pathogenicity assays and by serology $[1-3,5,28]$ and membrane protein analysis $[16,28,30]$. Serology differentiates $X$. citri subsp. citri from $X$. fuscans subsp. aurantifolii $[10,11,19]$. Strains of $X$. citri subsp. citri are susceptible to bacteriophage CP1 and CP2 whereas those of $X$. fuscans subsp. aurantifolii are not [18]. $X$. citri subsp. citri is differentiated from $X$. alfalfae subsp. citrumelonis by isozyme analysis [13]. $X$. citri subsp. citri grows on FS and $\mathrm{mSX}$ agars, utilizes arabinose, maltose, lactose, mannitol, cellobiose, and asparatic acid; hydrolyzes pectate, liquifies gelatin, and results in an alkaline hydrolysis of litmus milk [24].

Type strain: ICPB $10518=$ ATCC $49118=\mathrm{LMG}$ 9322.

Xanthomonas citri subsp. malvacearum (ex Smith 1901) subsp. nov., nom. rev.

Etymology: mal.va.ce.a'rum. N.L. pl. gen. n. malvacearum, of Malvaceae (of malvaceous plants of the family Malvaceae).

Description: X. citri subsp. malvacearum causes angular leaf spot and black arm of cotton (Gossypium hirsutum) whereas $X$. citri subsp. citri does not [24]. $X$. citri subsp. malvacearum is differentiated from $X$. campestris pv. campestris and most other Xanthomonas pathovars, subspecies, and species by DNA-DNA reassociation assays $[8,24,29]$, rep-PCR profiles [20], by serology [3], and SDS-PAGE patterns of membrane proteins [30], ITS sequencing [24], and phenotypic characters [24]. Strains of $X$. citri subsp. malvacearum produce single colonies on YDC and FS agars [23] after $40-44$ and $56-60 \mathrm{~h}$, respectively, at $28-30^{\circ} \mathrm{C}$ [24]. In contrast, $X$. fuscans subsp. fuscans and $X$. fuscans subsp. 
aurantifolii produce single colonies in 56-60 and 70-76h, respectively, and $X$. alfalfae subsp. alfalfae and $X$. alfalfae subsp. citrumelonis grow in 30-34 and 40-44 h, respectively [24]. Further, RFLP profiles differentiate $X$. citri subsp. malvacearum from $X$. fuscans subsp. fuscans, and $X$. alfalfae subsp. alfalfae [15]. $X$. campestris pv. campestris utilizes melizitose and hydrolyzes pectate whereas $X$. citri subsp. malvacearum does not [24]. $X$. citri subsp. malvacearum produces an alkaline reaction without hydrolysis in litmus milk whereas $X$. citri subsp. citri causes an alkaline reaction with hydrolysis [24]. X. citri subsp. malvacearum grows on FS and mSX agars [23], liquifies gelatin, and most strains $(60 \%)$ utilize maltose [24].

Type strain: ICPB $10528=$ ATCC $9924=$ ICMP $217=$ LMG 785 .

The type strain designated here, although identical in pathogenicity [24], is different from strain ICMP $5739=\mathrm{LMG} 761=\mathrm{NCPPB} 633$, indicated as the type strain for $X$. campestris pv. malvacearum ( $X$. axonopodis pv. malvacearum) $[7,29]$.

Xanthomonas fuscans sp. nov.

Etymology: fus'cans. L. part. adj. fuscans browning/ darkening.

Description: The description of the species $X$. fuscans is encompassed within the description of the genus Xanthomonas Dowson 1939 (Approved Lists 1980 [25]) emend. Vauterin et al., 1995 [29]. X. fuscans subsp. fuscans, causes blight of beans (Phaseolus vulgaris) and $X$. fuscans subsp. aurantifolii causes cankers on Citrus spp. whereas $X$. campestris and $X$. axonopodis do not affect either host [24]. X. fuscans is differentiated from all other xanthomonads, except $X$. campestris pv. vignicola, by production of a water soluble brown pigment on several common agar media including YDC [4,17,22-24]. Additionally, $X$. fuscans is differentiated from most other Xanthomonas pathovars and species by DNA-DNA reassociation assays [8,24,29], ITS sequencing [24], and rep-PCR profiles [20].

Type strain: ICPB $10520=$ ATCC $19315=$ ICMP $239=$ LMG $826=$ NCPPB 381.

Xanthomonas fuscans subsp. fuscans subsp. nov.

Etymology: fus'cans. L. part. adj. fuscans browning/ darkening.

Description: $X$. fuscans subsp. fuscans, originally described as Phytomonas phaseoli var. fuscans by Burkholder [4], causes fuscous blight of beans (Phaseolus vulgaris) whereas $X$. fuscans subsp. aurantifolii does not [24]. Fuscous blight may resemble common blight, caused by $X$. campestri pv. phaseoli. X. fuscans subsp. fuscans is differentiated from $X$. campestris pv. campestris by serology [27] and membrane protein analysis $[16,28]$. X. fuscans subsp. fuscans is differentiated from most other Xanthomonas pathovars, subspecies, and species by DNA-DNA reassociation assays [24,29], ITS sequences [24], rep-PCR profiles [20], RFLP profiles
[15], and phenotypic traits [24]. Strains of $X$. fuscans subsp. fuscans produce single colonies on YDC and FS agar after $56-60$ and $70-76 \mathrm{~h}$, respectively, at $28-30^{\circ} \mathrm{C}$ [24]. In contrast, $X$. citri subsp. citri and $X$. citri subsp. malvcearum produce single colonies in $40-44$ and 56-60 h, respectively, and $X$. alfalfae subsp. alfalfae and $X$. alfalfae subsp. citrumelonis grow in 30-34 and 40-44 h, respectively [24]. Strains of $X$. fuscans subsp. fuscans grow on FS and mSX agars [23], utilize maltose, hydrolyze pectin, and produce an alkaline hydrolysis of litmus milk [24]. X. fuscans subsp. fuscans produces a water soluble brown pigment on several common agar media including YDC [4,17,22-24]. Except for $X$. fuscans subsp. aurantifolii and $X$. campestris pv. vignicola, no other xanthomonad produces this brown pigment [24].

Type strain: ICPB $10520=$ ATCC $19315=\mathrm{ICMP}$ $239=$ LMG $826=$ NCPPB 381.

Xanthomonas fuscans subsp. aurantifolii subsp. nov.

Etymology: au.ran.ti.fol'i.i. N.L. n. Aurantium, a genus of citrus plants; N.L. gen. n. folii of/from a leaf; N.L. gen. n. aurantifolli of/from a citrus leaf.

Description: $X$. fuscans subsp. aurantifolii, originally described as a pathovar of $X$. campestris [9], causes cankers on Mexican lime (Citrus aurantifolia) [18] and occasionally on lemon (C. limon), orange ( $C$. sinensis), and grapefruit (C. paradisi) whereas $X$. fuscans subsp. fuscans does not affect citrus [24]. X. fuscans subsp. aurantifolii is differentiated from most other Xanthomonas pathovars, subspecies, and species by DNA-DNA reassociation assays $[8,24,29]$, rep-PCR profiles [20], ITS sequences [24], and phenotypic traits [24]. Strains of $X$. fuscans subsp. aurantifolii produce single colonies on YDC and FS agars [23] after 56-60 and 70-76h, respectively, at $28-30{ }^{\circ} \mathrm{C}$ [24]. In contrast, $X$. citri subsp. citri and $X$. citri subsp. malvacearum produce single colonies in 40-44 and 56-60 h, respectively, and $X$. alfalfae subsp. alfalfae and $X$. alfalfae subsp. citrumellonis grow in 30-34 and $40-44 \mathrm{~h}$, respectively [24]. $X$. fuscans subsp. aurantifolii is distinguished from $X$. citri subsp. citri and $X$. alfalfae subsp. citrumelonis as it precipitates litmus milk and hydrolyses gelatin. $X$. fuscans subsp. aurantifolii does not utilize maltose or hydrolyze pectate whereas $X$. citri subsp. citri and $X$. fuscans subsp. fuscans do [24]. $X$. fuscans subsp. aurantifolii precipitates litmus milk, whereas $X$. fuscans subsp. fuscans does not [24]. X. fuscans subsp. fuscans is distinguished from $X$. citri subsp. citri and $X$. campestris pv. campestris by failing to utilize arabinose and lactose [24]. Serology differentiates $X$. citri subsp. citri from $X$. fuscans subsp. aurantifolii $[10,11,19]$. Strains of $X$. citri subsp. citri are susceptible to bacteriophage CP1 and CP2 whereas those of $X$. fuscans subsp. aurantifolii are not [18]. Strains of $X$. fuscans subsp. aurantifolii utilize lactose, mannitol, and cellobiose and precipitate litmus milk [24]. Strains of $X$. fuscans subsp. aurantifolii 
produce a water-soluble brown pigment on several common agar media including YDC $[6,22,24]$. Except for $X$. fuscans subsp. fuscans and $X$. campestris $\mathrm{pv}$. vignicola, no other xanthomonad produces this brown pigment [24].

$$
2901 .
$$$$
\text { Type strain: } \mathrm{ICPB} 10470=\mathrm{NCPPB} 3236=\mathrm{CFBP}
$$

Xanthomonas alfalfae (ex Riker et al. 1935) sp. nov., nom. rev.

Etymology: al.fal'fae. N.L. gen. n. alfalfae from alfalfa (Medicago sativa).

Description: The description of the species $X$. alfalfae is encompassed within the description of the genus Xanthomonas Dowson 1939 (Approved Lists 1980 [25]) emend. Vauterin et al. 1995 [29]. Strains of X. alfalfae subsp. alfalfae cause leaf spots on alfalfa (Medicago sativa) and strains of $X$. alfalfae subsp. citrumelonis cause leaf spots on seedlings of Citrus spp. whereas other strains of $X$. campestris, $X$. axonopodis, and any other xanthomonads do not [24]. $X$. alfalfae is differentiated from other Xanthomonas pathovars, subspecies, and species by DNA-DNA reassociation assays [8,24,29], rep-PCR profiles [20], RFLP profiles [15], ITS sequences [24] and phenotypic traits [24]. $X$. alfalfae does not produce a brown water soluble pigment on common media as does $X$. fuscans and $X$. campestris pv. vignicola [24]. Strains of $X$. alfalfae grow much faster than other xanthomonads on SX and FS agars [23] and utilize a broader range of carbon sources [24]. $X$. alfalfae, and its subspecies, utilize arabinose, maltose, lactose, mannitol, and cellobiose; liquify gelatin; and produce an alkaline hydrolysis of litmus milk whereas $X$. axonopodis does not [24]. 495.

Type strain: $\mathrm{ICPB} 10701=\mathrm{ATCC} 11765=\mathrm{LMG}$

Xanthomonas alfalfae subsp. alfalfae (ex Riker et al., 1935) subsp. nov.

Etymology: al.fal'fae. N.L. gen. n. alfalfae from alfalfa (Medicago sativa).

Description: X. alfalfae subsp. alfalfae causes leaf spot of alfalfa [21] whereas $X$. alfalfae subsp. citrumelonis does not [24]. $X$. alfalfae subsp. alfalfae is distinguished from $X$. campestris pv. campestris and most other Xanthomonas pathovars, subspecies, and species by DNA-DNA reassociation assays [8,24,29], RFLP profiles [15], rep-PCR profiles [20], and ITS sequences [24]. Strains of $X$. alfalfae subsp. alfalfae produce single colonies on YDC and FS agarss [23] after 30-34 and $40-44 \mathrm{~h}$, respectively, at $28-30^{\circ} \mathrm{C}$ [24]. In contrast, $X$. citri subsp. citri and $X$. citri subsp. malvcearum produce single colonies in 40-44 and 56-60 h, respectively, and $X$. fuscans subsp. fuscans and $X$. fuscans subsp aurantifolii grow in 56-60 and 70-76h, respectively [24]. X. alfalfae subsp. alfalfae produces acid from most carbon sources whereas $X$. campestris pv. campestris does not [24]. $X$. campestris pv. campestris utilizes raffinose whereas $X$. alfalfae subsp. alfalfae does not [24]. X. alfalfae subsp. alfalfae grows faster on YDC agar than do most other xanthomonads [24]. Strains of $X$. alfalfae subsp. alfalfae produce an alkaline reaction on saccharic acid whereas strains of $X$. alfalfae subsp. citrumelonis do not [24]. $X$. alfalfae subsp. alfalfae utilizes arabinose, maltose, lactose, mannitol, melizitose, and cellobiose, liquifies gelatin, and produces an alkaline hydrolysis of litmus milk [24].

Type strain: ICPB $10701=\mathrm{ATCC} 11765=\mathrm{LMG}$ 495.

Xanthomonas alfalfae subsp. citrumelonis subsp. nov.

Etymology: ci.tru.me'lo.nis. N.L. gen. n. citrumelonis of citrumelo (Citroncirus sp.; hybrid of Citrus paradisi $\mathrm{x}$ Poncirus trifoliata).

Description: $X$. alfalfae subsp. citrumelonis, originally described as pathovar "citrumelo" of $X$. campestris [9], causes citrus bacterial spot [12]; $X$. alfalfae subsp alfalfae does not [24]. X. alfalfae subsp citrumelonis is distinguished from $X$. campestris pv. campestris and other Xanthomonas pathovars, subspecies, and species by DNA-DNA reassociation assays [8,24,29], rep-PCR profiles [20], ITS sequences [24], and phenotypic traits [24]. Strains of $X$. alfalfae subsp. citrumelonis produce single colonies on YDC and FS agars [23] after 30-34 and $40-44 \mathrm{~h}$, respectively, at $28-30^{\circ} \mathrm{C}$ [24]. In contrast, $X$. citri subsp. citri and $X$. citri subsp. malvacearum produce single colonies in 40-44 and 56-60 h, respectively, and $X$. fuscans subsp. fuscans and $X$. fuscans subsp. aurantifolii grow in 56-60 and $70-76 \mathrm{~h}$, respectively [24]. $X$. alfalfae subsp. citrumelonis strains are differentiated from $X$. citri subsp. citri and $X$. citri subsp. malvacearum and $X$. fuscans subsp. aurantifolii by serological assays $[2,12,19]$. X. alfalfae subsp. citrumelonis utilizes raffinose whereas $X$. alfalfae subsp. alfalfae, $X$. citri subsp. citri, and $X$. citri subsp. malvacearum strains do not [24]. $X$. alfalfae subsp. alfalfae and $X$. alfalfae subsp. citrumelonis can be differentiated from $X$. fuscans subsp. aurantifolii on their more rapid growth on agar media, liquefaction of gelatin, and utilization of maltose [24]. $X$. alfalfae subsp. citrumelonis is distinguished from $X$. citri subsp. citri by utilizing raffinose, producing acid from cellobiose and mannitol, and growing faster on YDC and FS agars [24]. All strains of $X$. alfalfae subsp. citrumelonis utilize mannitol and raffinose whereas strains of $X$. citri subsp. malvacearum do not [24].

Type strain: ICPB $10483=$ ATCC $49120=\mathrm{LMG}$ 9325.

\section{Acknowledgements}

We thank Dr. J.P. Euzeby for proof reading our protologues and Dr. B.J. Tindall and Dr. J.M. Young for reviewing our nomenclature. 


\section{References}

[1] A.M. Alvarez, A.A. Benedict, C.Y. Mizumoto, Identification of xanthomonads and grouping of strains of Xanthomonas campestris pv. campestris with monoclonal antibodies, Phytopathology 75 (1985) 722-728.

[2] A.M. Alvarez, A.A. Benedict, C.Y. Mizumoto, L.W. Pollard, E.L. Civerolo, Analysis of Xanthomonas campestris pv. citri and Xanthomonas campestris pv. citrumelo with monoclonal antibodies, Phytopathology 81 (1991) $857-865$.

[3] R.H. Brlansky, R.F. Lee, E.L. Civerolo, Detection of Xanthomonas campestris pv. citrumelo and $X$. citri from citrus using membrane entrapment immuno-fluorescence, Plant Dis. 74 (1990) 863-868.

[4] W.H. Burkholder, The bacterial diseases of bean. A comparative study. Memiors of the Cornell Agricultural Research Station No. 127, 1930.

[5] E.L. Civerolo, F. Fan, Xanthomonas campestris pv. citri detection and identification by enzyme-linked immunosorbent assay, Plant Dis. 66 (1982) 231-236.

[6] S.A.L. Destefano, N.J. Rodrigues, Characterization of pigment producer strains of Xanthomonas axonopodis pv. aurantifolii (C Type), Summa Phytopathol. 27 (2002) 287-291.

[7] D.W. Dye, J.F. Bradbury, M. Goto, A.C. Hayward, R.A. Lelliot, M.N. Schroth, International standards for naming pathovars of phytopathogenic bacteria and a list of pathovar names and pathotype strains, Rev. Plant Pathol. 59 (1980) 153-168.

[8] D.S. Egel, J.H. Graham, R.E. Stall, Genomic relatedness of Xanthomonas campestris strains causing diseases of citrus, Appl. Environ. Microbiol. 57 (1991) 2724-2730.

[9] D.W. Gabriel, M.T. Kingsley, J.E. Hunter, T. Gottwald, Reinstatement of Xanthomonas citri (ex Hasse) and $X$. phaseoli (ex Smith) to species and reclassification of all $X$. campestris pv. citri strains, Int. J. Syst. Bacteriol. 39 (1989) 14-22.

[10] M. Goto, Citrus canker, in: J. Kumar, H.S. Choube, U.S. Sing, A.N. Mukhopadhay (Eds.), Plant Diseases of International Importance, Vol. III. Diseases of Fruit Crops, Prentince-Hall, Englewood Cliffs, 1992, pp. 170-208.

[11] M. Goto, A. Toyoshima, M.A. Messina, A comparative study of the strains of Xanthomonas campestris pv. citri isolated from citrus canker in Japan and cancrosis B in Argentina, Ann. Phytopathol. Soc. Jpn 46 (1980) 329-338.

[12] T.R. Gottwald, A.M. Alvarez, J.S. Hartung, A.A. Benedict, Diversity of Xanthomonas campestris pv. citrumelo strains associated with epidemics of citrus bacterial spot in Florida citrus nurseries: correlation of detached leaf, monoclonal antibody, and restriction fragment length polymorphism assays, Phytopathology 81 (1991) 749-753.

[13] Q.B. Kubicek, E.L. Civerolo, M.R. Bonde, J.S. Hartung, G.L. Peterson, Isozyme analysis of Xanthomonas campestris pv. citri, Phytopathology 79 (1989) 297-300.

[14] S.P. Lapage, P.H.A. Sneath, E.F. Lessel, V.B.D. Skerman, H.P.R. Seeliger, W.A. Clark (Eds.), International
Code of Nomenclature of Bacteria (1976 Revision). Bacteriological Code, American Society for Microbiology, Washington, DC, 1976.

[15] G.R. Lazo, R. Roffey, D.W. Gabriel, Pathovars of Xanthomonas campestris are distinguished by restriction fragment length polymorphisms, Int. J. Syst. Bacteriol. 37 (1987) 214-221.

[16] G.V. Minsavage, N.W. Schaad, Characterization of membrane proteins of Xanthomonas campestris pv. campestris, Phytopathology 73 (1983) 747-755.

[17] A.B.C. Mkandawire, R.B. Mabagala, P. Guzman, P. Gepts, R.L. Gilbertson, Genetic diversity and pathogenic variation of common bacterial blight bacteria (Xanthomonas campestris pv. phaseoli and $X$. campestris pv. phaseoli var. fuscans) suggests pathogenic coevolution with the common bean, Phytopathology 94 (2004) 593-603.

[18] T. Namekata, Estudos Comparativos Entre Xanthomonas citri [Hasse] Dow., Agente Causal do Cancro Citrico e Xanthomonas Citri [Hasse] Dow, N.F.SP. aurantifolia, Agente Causal da Cancrose do limoeiro Galego. 65f. Tese (Doutoramento) - Escola Superior de Agricultura "Luiz de Queiroz", Universidade de Sao Paulo, Piracicaba, 1971.

[19] T. Namekata, A.R. de Oliveira, Comparative serological studies between Xanthomonas citri and a bacterium causing canker on Mexican lime, in: Proceedings of International Conference on Plant Pathogenic Bacteria, Wageningen, The Netherlands, 1972, pp. 151-152 (365pp).

[20] J.L.W. Rademaker, F.J. Louws, M.H. Schultz, U. Rossbach, L. Vauterin, J. Swings, F.J. de Bruijn, A comprehensive species to strain taxonomic framework for Xanthomonas, Phytopathology 95 (2005) 1098-1111.

[21] A.J. Riker, F.R. Jones, M.C. Davis, Bacterial leaf spot of alfalfa, J. Agric. Res. 51 (1935) 177-182.

[22] N.W. Schaad, Initial identification of common genera, in: N.W. Schaad, J.B. Jones, W. Chun (Eds.), Laboratory Guide for Identification of Plant Pathogenic Bacteria, third ed, APS Press, St. Paul, MN, 2001, pp. 1-16 (373pp).

[23] N.W. Schaad, J.B. Jones, G.H. Lacy, Xanthomonas, in: N.W. Schaad, J.B. Jones, W. Chun (Eds.), Laboratory Guide for Identification of Plant Pathogenic Bacteria, third ed, APS Press, St. Paul, MN, 2001, pp. 175-200 (373pp).

[24] N.W. Schaad, E. Postnikova, G.H. Lacy, A. Sechler, I. Agarkova, P.E. Stromberg, V.K. Stromberg, A.K. Vidaver, Reclassification of Xanthomonas campestris pv. citri (ex Hasse 1915) Dye 1978 forms A, B/C/D, and E as $X$. smithii subsp. citri (ex Hasse) sp. nov. nom. rev. comb. nov., X. fuscans subsp. aurantifolii (ex Gabriel 1989) sp. nov. nom. rev. comb. nov., and $X$. alfalfae subsp. citrumelo (ex Riker and Jones) Gabriel et al., 1989 sp. nov. nom. rev. comb. nov.; X. campestris pv. Malvacearum (ex Smith 1901) Dye 1978 as $X$. smithii subsp. smithii nov. comb. nov. nom. nov.; $X$. campestris pv. alfalfae (ex Riker and Jones, 1935) Dye 1978 as X. alfalfae subsp. alfalfae (ex Riker et al., 1935) sp. nov. nom. rev.; and "var. fuscans" of X. campestris pv. phaseoli (ex Smith, 
1987) Dye 1978 as $X$. fuscans subsp. fuscans sp. nov, Syst. Appl. Microbiol. 28 (2005) 494-518.

[25] V.B.D. Skerman, V. McGowan, P.H.A. Sneath (Eds.), Approved lists of bacterial names, Int. J. Syst. Bacteriol. 30 (1980) 225-420.

[26] E. Stackebrandt, W. Frederiksen, G.M. Garrity, P.A.D. Grimont, P. Kampfer, M.C.L. Maiden, X. Nesme, R. Rossello-Mora, J. Swings, H.G. Truper, L. Vauterin, A.C. Ward, W.B. Whitman, Report of the ad hoc committee for the re-evaluation of the species definition in bacteriology, Int. J. Syst. Evol. Microbiol. 52 (2002) $1043-1047$.

[27] X. Sun, R.E. Stall, J.B. Jones, J. Cubero, T.W. Gottwald, J.H. Graham, W.N. Dixon, T.S. Schubert, P.H. Chaloux, V.K. Stromberg, G.H. Lacy, B.D. Sutton, Detection and characterization of a new strain of citrus canker bacteria from Key/Mexican lime and alemow in South Florida, Plant Dis. 88 (2004) 1179-1188.

[28] N. Thaveechai, N.W. Schaad, Serological and electrophoretic analysis of a membrane protein of Xanthomonas campestris pv. campestris from Thailand, Phytopathology 76 (1986) 139-147.

[29] L. Vauterin, B. Hoste, K. Kersters, J. Swings, Reclassification of Xanthomonas, Int. J. Syst. Bacteriol. 45 (1995) 472-489.

[30] L. Vauterin, P. Yang, B. Hoste, M. Vancanneyt, E.L. Civerolo, J. Swings, K. Kersters, Differentiation of
Xanthomonas campestris pv. citri strains by sodium dodecyl sulfate-polyacrylamide gel electrophoresis of proteins, fatty acid analysis, and DNA-DNA hybridization, Int. J. Syst. Bacteriol. 41 (1991) 535-542.

[31] L.G. Wayne, D.J. Brenner, R.R. Colwell, P.A.D. Grimont, O. Kandler, M.I. Krichevsky, L.H. Moore, W.E.C. Moore, R.G.E. Murray, E. Stackebrandt, M.P. Starr, H.G. Trüpper, Report of the ad hoc committee on the reconciliation of approaches to bacterial systematics, Int. J. Syst. Bacteriol. 37 (1987) 463-464.

[32] E. Yabuuchi, P. De Vos, Minutes of the meetings of the international committee of systematic bacteriology subcommittee on the taxonomy of the genus Pseudomonas and related organisms (17 and 20 September 1990, Japan), Int. J. Syst. Bacteriol. 45 (1995) 877-878.

[33] P. Yang, L. Vauterin, M. Vancanneyt, J. Swings, K. Kersters, Application of fatty acid methyl esters for taxonomic analysis of the genus Xanthomonas, Syst. Appl. Microbiol. 16 (1993) 47-71.

[34] J.M. Young, J.F. Bradbury, L. Gardan, R.I. Gvozdyak, D.E. Stead, Y. Takikawa, A.K. Vidaver, Comment on the reinstatement of Xanthomonas citri (ex Hasse 1915) Gabriel et al. 1989 and X. phaseoli (ex Smith 1897) Gabriel et al. 1989. Indication of the need for minimal standards for the genus Xanthomonas, Int. J. Syst. Bacteriol. 41 (1991) 172-177. 